\title{
Medullary Thyroid Carcinoma Clinical TNM Finding v8
}

National Cancer Institute

\section{Source}

National Cancer Institute. Medullary Thyroid Carcinoma Clinical TNM Finding v8. NCI

Thesaurus. Code C141007.

A clinical finding about one or more characteristics of medullary thyroid carcinoma, following the rules of the TNM AJCC v8 classification system. 